\title{
Production of Ductile Iron Using Indigenously Manufactured Rotary Furnace
}

\author{
O.A. Adeyemi ${ }^{1}$, I.M. Momoh ${ }^{2}$, S.O.O. Olusunle ${ }^{1}$ and S.B. Adejuyigbe ${ }^{3}$ \\ ${ }^{1}$ Engineering Materials Development Institute, Akure, Nigeria. \\ ${ }^{2}$ Depertment of Metallurgy, Kogi State Polytechnic, Lokoja, Nigeria. \\ ${ }^{3}$ Federal University of Agriculture, Abeokuta, Nigeria.
}

\begin{abstract}
Production of ductile iron using an indigenous $100 \mathrm{~kg}$ rotary furnace was achieved using the ladle treatment/sandwich cover ladle method. Powdered Ferrosilicon magnesium of $400 \mathrm{~g}$ was used as a nodularizer together with powdered Ferrosilicon of $20 \mathrm{~g}$ was used as innoculant. The nodularizer was put in a cylindrical pocket at the base of the ladle with a circular fitting steel plate cover welded to a handle which was removed immediately after tapping the molten metal from the rotary furnace. The resulting melt was subsequently poured into the mould after the violent reaction between the molten metal and the nodularizer. Samples of the as-cast were subjected to metallographic process and characterized using a Nikon Eclipse metallurgical microscope and a Hilger Analytica atomic mass absorption spectrometer for percentage elemental analysis. The average percentage element weight of the samples and microstructures of $200 X$ and $400 X$ compared favourably with the ductile iron produced from standard procedure.
\end{abstract}

Keywords: ductile iron, rotary furnace, nodularizer, microstructures.

\section{Introduction}

Ductile iron, also called ductile cast iron, spheroidal graphite iron, or nodular cast iron, is a type of cast iron invented in 1943 by Keith Millis. While most varieties of cast iron are brittle, ductile iron is much more flexible and elastic, due to its nodular graphite inclusions. The graphite enhances the desirable properties of cast iron like improved casting \& machining properties and better thermal conductivity. In ductile iron, the graphite is in the form of spherical nodules- rather than flakes which is found in typical cast iron- which inhibit the creation of cracks and providing the enhanced ductility that gives the alloy its name. The formation of nodules is achieved by addition of nodularizers (for example, magnesium or cerium) into the melt. Ductile iron has enormous advantages over its steel counterpart; it has better mechanical properties with wide range of applications in the automotive industry [1], defence [2], agriculture [3,4], construction and mining components [5] e.t.c.

Rotary furnace is a typical example of a fuel-fired furnace which is known for its ease in operation, low cost of operation, fuel economy, low cost of manufacture, high thermal efficiency and low maintenance. The rotary furnace consists of a cylindrical, refractory lined steel drum supported by a structural steel frame, inbetween two conical frustums. The conical frustums are of two different diameters. The primary heat source of the furnace could either be a natural gas burner or a liquid fuel burner [6,7].

To this end, this work intends to show that ductile iron production can be achieved using an indigenously manufactured rotary furnace.

\section{Experimental Work}

\section{Charge Material for Ductile Iron}

Cast iron scrap (engine sleeve Carbon 2.8-3.3; Silicon 1.8-2.5; Manganese 0.5-0.8; Phosphorus 0.3 max and Sulphur 0.12max ASTM E-535) of about 40kg was used. The nodularizer, powdered Ferrosilicon Magnesium of about $400 \mathrm{~g}$ was used; Ferrosilicon of about $20 \mathrm{~g}$ was used as the inoculant. The ladle treatment/sandwich method developed by Skjegestad and Skaland was adopted for the ladle design. The ladle was prepared having a pocket at the base of the ladle with ferrosilicon magnesium deposited and covered with tiny mild steel plates and a Y-block patterned mould was prepared, using green sand.

\subsection{Production Process of Ductile Iron Production}

The first stage was to preheat the rotary furnace for about seventy minutes before charging the $40 \mathrm{~kg}$ scrap. The inoculant was subsequently added thereafter to the melt in the furnace according to Olusunle procedure [8]. The melt was subsequently tapped into the ladle where a violent reaction between the melt and the nodularizer was observed for about 10 seconds before being poured into the mould. Two different melting operations were carried out and the melts were tapped at temperature $1480^{\circ} \mathrm{C}$ and $1500^{\circ} \mathrm{C}$ respectively. 


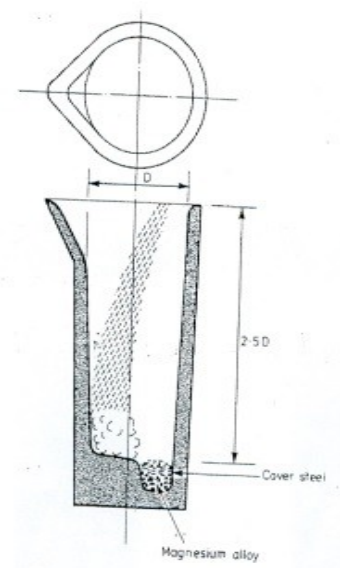

FIGURE 2: Sandwich Cover Ladle Design [9].

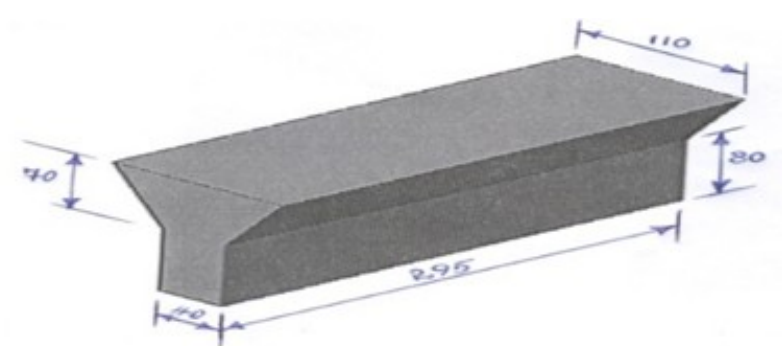

FIGURE 3: Y- Block Pattern used for Ductile Iron Production [2]

\section{1}

\section{Results And Discussions}

\section{Chemical Composition of Ductile Iron}

The as cast samples were subjected to the Hilger Analytica atomic mass absorption spectrometer for chemical composition analysis. The table below shows the weight percent of the elements in the 10 samples.

TABLE 3.0: Elemental Chemical Composition of Ductile Iron Samples

\begin{tabular}{|l|l|l|l|l|l|l|}
\hline ELEMENT (Wt\%) & $\mathbf{C}$ & $\mathbf{S i}$ & $\mathbf{M n}$ & $\mathbf{M g}$ & $\mathbf{S}$ & $\mathbf{P}$ \\
\hline SAMPLE 1 & 3.60 & 2.10 & 0.30 & 0.05 & 0.009 & 0.04 \\
\hline SAMPLE 2 & 3.60 & 2.00 & 0.25 & 0.04 & 0.009 & 0.035 \\
\hline SAMPLE 3 & 3.40 & 2.10 & 0.30 & 0.04 & 0.010 & 0.035 \\
\hline SAMPLE 4 & 3.50 & 2.00 & 0.30 & 0.05 & 0.009 & 0.035 \\
\hline SAMPLE 5 & 3.50 & 2.00 & 0.20 & 0.05 & 0.009 & 0.035 \\
\hline SAMPLE 6 & 3.60 & 2.00 & 0.20 & 0.05 & 0.01 & 0.04 \\
\hline SAMPLE 7 & 3.60 & 2.00 & 0.25 & 0.05 & 0.01 & 0.04 \\
\hline SAMPLE 8 & 3.60 & 2.10 & 0.30 & 0.04 & 0.01 & 0.04 \\
\hline SAMPLE 9 & 3.50 & 2.00 & 0.25 & 0.05 & 0.01 & 0.04 \\
\hline SAMPLE 10 & 3.60 & 2.00 & 0.30 & 0.04 & 0.01 & 0.03 \\
\hline TOTAL & 35.50 & 20.30 & 2.65 & 0.46 & 0.096 & 0.37 \\
\hline AVERAGE & $\mathbf{3 . 6 0}$ & $\mathbf{2 . 0 0}$ & $\mathbf{0 . 3 0}$ & $\mathbf{0 . 0 5}$ & $\mathbf{0 . 0 1}$ & $\mathbf{0 . 0 4}$ \\
\hline
\end{tabular}

SOURCE: Adeyemi (2007)

The percentage carbon value was more than the value range of the engine sleeve scrap used. The Silicon and Manganese values of cast produced using the rotary furnace was within the range of values of the engine sleeve scrap. The Phosphorus and Sulphur values were well below the maximum values of the sleeve scrap used.

\subsection{Micrographs of Ductile Iron}

The samples were also subjected to metallographic process and characterized using the Nikon Eclipse metallurgical microscope. The microstructures below reveals its morphology. 


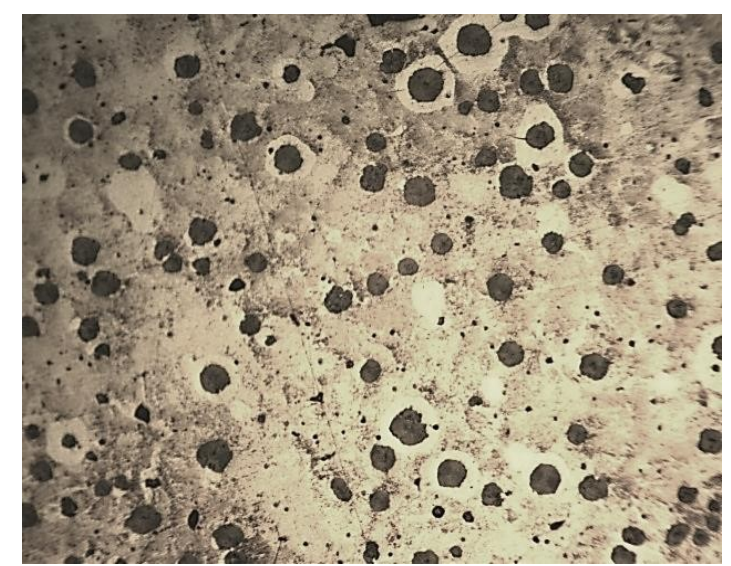

Figure 3(a): Microstructure of ductile iron produced from indigenously manufactured rotary furnace (200X).

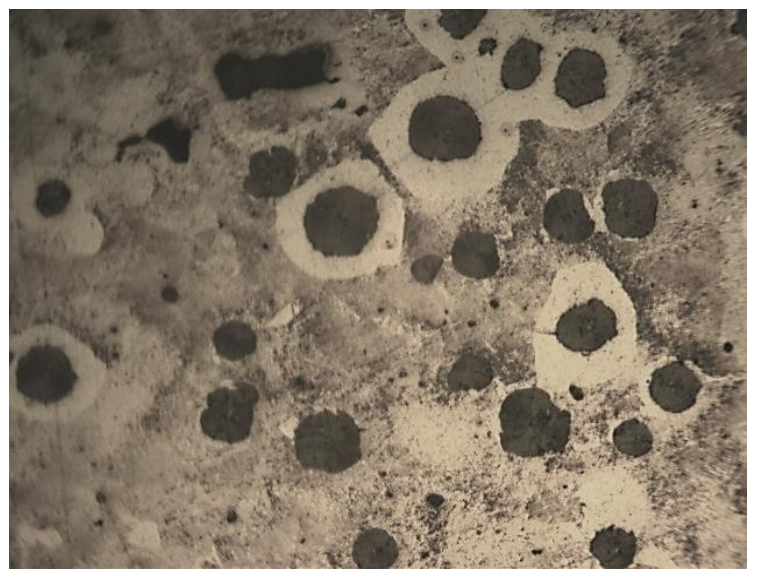

Figure 3(b): Microstructure of ductile iron produced from indigenously manufactured rotary furnace (400X).

The microstructure shows graphite globules dispersed all over the pearlite ferrite matrix. Some globules are seen surrounded by ferrite matrix, this is the characteristic bullseye structure peculiar to ductile iron.

\section{Conclusion}

The values of the chemical composition of the cast was found to be similar to that of the 500-7 SG Iron grade. Its values are:

$\begin{array}{llll}\text { Carbon } & 3.40-3.85 \% & \text { Phosphorous } & 0.10 \% \max \\ \text { Manganese } & 0.10-0.30 \% & \text { Sulphur } & 0.02 \% \max \\ \text { Silicon } & 2.30-3.10 \% & \text { Magnesium } & 0.07 \% \max \\ & & \text { Iron } & \text { balance }\end{array}$

Also, the microstructure of the samples compared favourably with the standard micro structure of ductile iron, showing the characteristic 'bulleye' feature.

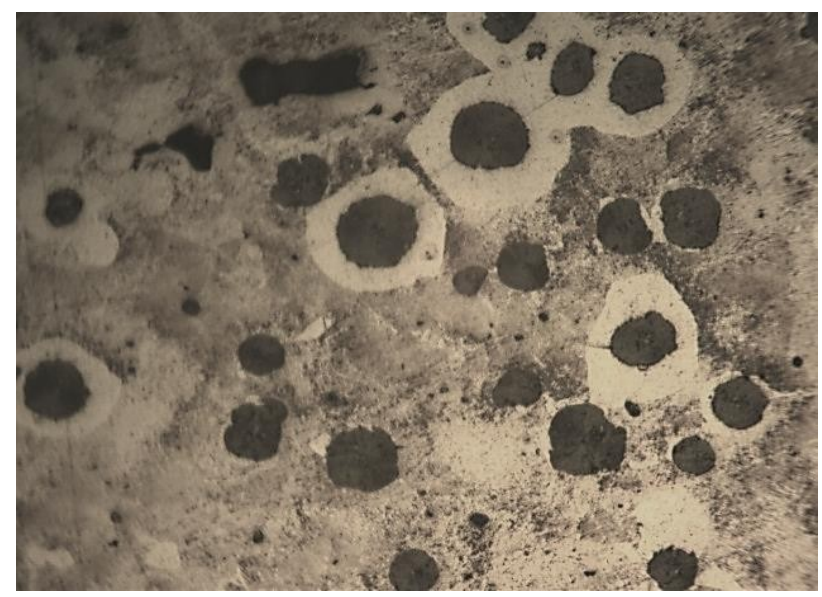




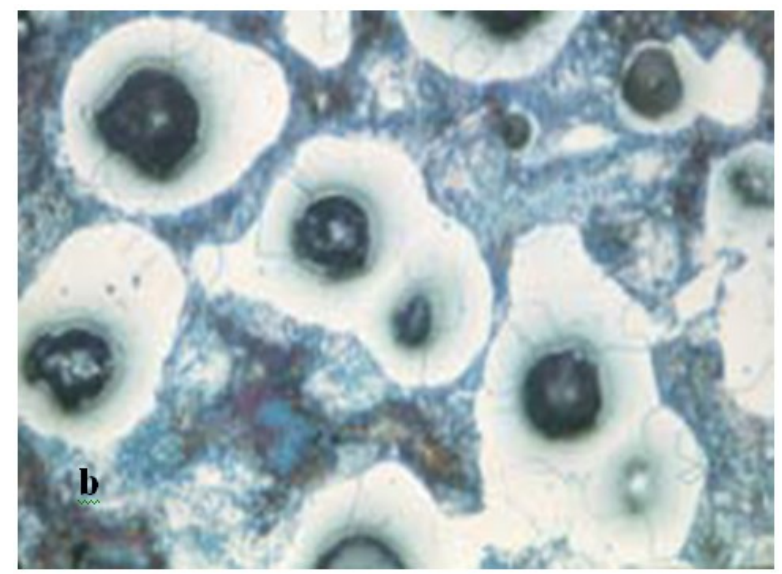

Figure 4: Showing the microstructure of ductile iron produced from [400X] (a) EMR100 rotary furnace and (b) ductile iron produced from induction furnace. Source: (a) Adeyemi (2007); (b) ASM Handbook (2004)

\section{Acknowledgment}

The authors of these work appreciates the support and contribution of the technical staff and management of Engineering Materials Development Institute, Akure, Nigeria for the rotary furnace - EMR 100 - used for this project.

\section{Reference}

[1] Nofal A.A., Jekova L. (2009): Novel Processing Techniques And Applications Of Austempered Ductile Iron (Review). Journal of the University of Chemical Technology and Metallurgy, vol. 44, issue 3, pp. 213-228.

[2] America Foundry Society (AFS): Achieving Lightweight Casting Solutions (ALCS) Using American Foundries for Army Defense Applications.

[3] BŘEZINA R., FILÍPEK J., ŠENBERGER J. (2004): Application of ductile iron in the manufacture of ploughshares. RES. AGR. ENG., 50, (2): 75-80.

[4] Dervi P., Mirsada O.(2007): The Application of Spheroidal Graphite Cast Iron in Bosnia and Herzegovina. Materials and Technology MT AEC9. Vol. 41 Issue 4, pp. 193-195.

[5] Huggett P., Wuhrer R., Ben-Nissan B. and Moran K. (2006): Composite Alloy Wear Parts for Use In The Mining Industry. Materials forum volume 30 .

[6] EMDI (2007): Working Manual of EMR-100 Rotary Furnace, Prepared by Engineering Materials Development Institute, Akure.

[7] Krivadin V.A. and Markov B.L. (1980): Metallurgical Furnaces, MIR Publishers, Moscow.

[8] Olusunle S.O.O. (2012): Development and Characterisation of Austempered Rotary-Furnace-Melt Treated Nickel-Chromium Alloyed Ductile Irons. PhD Thesis, ObafemiAwolowo University, Ile Ife, Osun State, Nigeria.

[9] Elkem Technical Information Sheets (2002): A Publication of Elkem Technologies, Oslo.

[10] ASM Metals Handbook (1990): Tenth Edition, American Society of Metals Publication, Metals Park

[11] Adeyemi O.A. (2007): Production of ductile iron using a locally developed rotary furnace. Unpublished M.Eng. Thesis, Federal University of Technology Akure, Ondo State, Nigeria. 